\title{
Effects of correcting in situ ruminal microbial colonization of feed particles on the relationship between ruminally undegraded and intestinally digested crude protein in concentrate feeds
}

Javier González*, Rabiaa Mouhbi, Jesús Alberto Guevara-González, José María Arroyo

Departamento de Producción Agraria, Escuela Técnica Superior de Ingeniería Agronómica, Alimentaria y de Biosistemas, Universidad Politécnica de Madrid, Ciudad Universitaria, 28040 Madrid, Spain

Running title: effect of rumen-microbial colonization on intestine-digested protein prediction

*Corresponding author: javier.gonzalez@upm.es

\begin{abstract}
BACKGROUND: In situ estimates of ruminally undegraded protein (RUP) and intestinally digested protein (IDP) of ten concentrates, uncorrected or corrected for the ruminal microbial colonization, were used to examine the effects of this correction on the relationship between IDP and RUP values. Both variables were established for three rumen and duodenum cannulated wethers using ${ }^{15} \mathrm{~N}$ labeling-techniques and considering measured rates of ruminal particle comminution $\left(k_{c}\right)$ and outflow $\left(k_{p}\right)$.

RESULTS: A covariance analysis showed that the close relationship found between both variables (IDP $=-0.0132( \pm 0.00679)+0.776( \pm 0.0002)$ RUP; $\mathrm{n}=60 ; P<0.001$; $\left.\mathrm{R}^{2}=0.960\right)$ is not affected by correcting for microbial colonization $(P=0.682)$.

CONCLUSION: The IDP content in concentrates and industrial by-products can be predicted from RUP values, thus avoiding the laborious and complex procedure of determining intestinal digestibility; however a larger sample of feeds is necessary to attain more accurate predictions. The lack of influence of the correction for microbial contamination on the prediction observed in our study increases the data available for this prediction. However, only using corrected values may provide an accurate evaluation.
\end{abstract}

This article has been accepted for publication and undergone full peer review but has not been through the copyediting, typesetting, pagination and proofreading process, which may lead to differences between this version and the Version of Record. Please cite this article as doi: 10.1002/jsfa.8534 
Keywords: protein; ruminal degradability; intestinal digestibility; microbial contamination; sheep

\section{Introduction}

The feed protein evaluation in most current rationing systems for ruminants considers the supply of ruminally degraded and undegraded protein, the synthesis of microbial protein in the rumen and the intestinal digestion of the post-ruminal flow of protein. For dietary protein, the rate and extent of ruminal degradation are not only major determinants of this protein flow, but also of its composition and, therefore, of its intestinal digestion ${ }^{1,2}$. The in situ methods are suitable to perform systematic measures of ruminal and intestinal digestion of multiple feeds; therefore, their results, and especially those of ruminal degradability, are used in numerous feed rationing systems such as $\mathrm{NRC}^{3}, \mathrm{INRA}^{4}, \mathrm{DVE} \mathrm{OEB}^{5}$ and Norfor ${ }^{6}$. However, these methods may present some accuracy problems, such as the colonization of ruminal undigested residues with adherent microorganisms, which will be largely digested during the intestinal incubations. As a consequence, both estimates (ruminal degradability and intestinal digestibility) are biased. In addition, as ruminal degradation determines the digestion site, any error made in this determination leads to another in the intestinal digestibility estimates. Therefore, it is advisable to consider the total rumen residence time of feed particles as determined by their outflow rate from the reticulum $\left(k_{p}\right)$ as well as by their rate of comminution and mixing $\left(k_{c}\right)^{7,8}$, although the latter rate is often not considered in in situ studies. Based on the previously indicated interrelation between ruminal degradation characteristics and intestinal digestion, the objective of this work was to investigate the possible relationship between the contents of intestinally digested crude protein (IDP) and ruminally non-degraded protein (RUP) of concentrate feeds and to evaluate the effects of correcting the microbial colonization taking place in the rumen on this relationship.

\section{Materials and methods}

\subsection{Experimental}

Ten samples of concentrates and industrial by-products of the food industry were tested in one experiment on three wethers fitted with rumen and T-type duodenal cannula and fed a ration with a 2:1 ratio (fresh matter basis) of chopped oat hay to commercial 
concentrate. The chemical composition of the tested feeds as well as that of oat hay and concentrate is shown in Table 1. This diet was fed 10 days before the onset of the experimental period, at $40 \mathrm{~g} \mathrm{~kg}^{-1}$ body weight ${ }^{0.75}$ divided in six equal meals offered every 4 hours. The animals were handled in accordance with the Spanish guidelines for experimental animal protection, published in the Royal Decree 53/2013 ${ }^{9}$. The values for microbial contamination, RUP and IDP measured for different feeds in the animal experiment and used in this study are shown in Table 2.

In situ studies included nylon-bag incubations in rumen and intestine, as well as measurement of the ruminal transit of dietary concentrate particles and the correction of the microbial colonization taking place in the rumen in both types of samples. Ruminal incubations were performed for 2, 4, 8, 16, 24 and $48 \mathrm{~h}$ using nylon bags (46 $\mu \mathrm{m}$ of pore size and internal dimension of $110 \times 70 \mathrm{~mm}$ ). Bags were filled with approximately $3 \mathrm{~g}$ (air-dry basis) of each feed previously ground to pass a $2 \mathrm{~mm}$ screen. A total of 10 incubations carried out in two periods of five incubations were performed in order to have two bags for each incubation time and feed. In each incubation all bags of the different incubation times (6 for each feed) of two randomly associated feeds were simultaneously placed in the rumen immediately before the first meal in the morning (0900 h). After being collected from the rumen, bags were washed with tap water and stored at $-20^{\circ} \mathrm{C}$. After thawing, bags were washed three times for 5 minutes in a miniturbine washing machine (Jata 580; JATA, Abadiano, Bizkaia, Spain) and frozen again $\left(-20^{\circ} \mathrm{C}\right)$. Finally, bags were freeze-dried and immediately weighed to establish DM degradation kinetics. Between both periods of ruminal incubations, the rates of particle comminution $\left(k_{c}\right)$ and transit $\left(k_{p}\right)$ in the rumen-reticulum were determined. For this purpose the wethers were pulse-dosed before the first morning meal with $50 \mathrm{~g}$ of the dietary concentrate labelled with Ytterbium (using a solution of $\mathrm{YbCl}_{3}$ ) and the marker evolution was checked in 21 duodenal samples recovered during the following $96 \mathrm{~h}$. The model of Dhanoa et al. ${ }^{10}$ was fitted to the marker concentration data of each animal and primary and secondary rate constants of this model were assumed as $k_{p}$ and $k_{c}$ values, respectively, in agreement with Ellis et al. ${ }^{7}$ and González et al. ${ }^{8}$. To account for the above mentioned microbial colonization, a solution of ${ }^{15} \mathrm{~N}$ enriched ammonium sulphate (98 atoms\%) was continuously infused into the rumen $\left(25 \mathrm{mg}{ }^{15} \mathrm{~N}\right.$ per wether and day) during these incubations, up to the isolation of solid adherent bacteria, which were used as reference for these corrections. For this purpose, the rumen was manually

This article is protected by copyright. All rights reserved. 
emptied and a representative sample of $1.2 \mathrm{~kg}$ was subjected to a double centrifugation procedure, as described by Rodríguez et al. $(2000)^{11}$. Degradation kinetics of DM were fitted to the single exponential model of Ørskov and McDonald ${ }^{12}$, except in some feeds which needed specific models: corn gluten feed, which showed two consecutive single exponential curves ${ }^{2}$, and dehydrated sugar beet pulp, which showed a sigmoid evolution ${ }^{13}$. Estimates of RUP were established by generating in each wether a composite sample representative of the feed by-pass based on the function describing the feed rumen outflow developed by Arroyo and González ${ }^{14}$ considering $k_{c}$ and $k_{p}$ particle transit rates and DM degradation kinetics. To generate these composite samples, the residues obtained at each incubation time for each animal were pooled in equal quantities. Then, the resultant residues for $0,2,4,8,16,24$ and $48 \mathrm{~h}$ of incubation were considered representative of the composition of the rumen outflow of undegraded feed in the intervals $0-1,1-3,3-6,6-12,12-20,20-36$ and 36-72 h, respectively. Finally, the rumen outflow of undegraded feed in these intervals was established by the above indicated function of Arroyo and González ${ }^{14}$ and the proportions in which the different residues were mixed were calculated by the quotient between the flow in each interval and the total flow. These composite samples were analysed for CP to determine RUP values and also incubated through the intestine in mobile nylon bags to establish intestinal digestibility values. To avoid errors in the correction of the ruminal microbial colonization of the intestinal undigested samples, these incubations were performed after a 10-day resting period from the ruminal study to eliminate the ${ }^{15} \mathrm{~N}$ enrichment in the digesta. Mobile bags were randomly inserted through the duodenal cannula at a rate of one bag every $15 \mathrm{~min}$ ( 8 bags per wether and day), recovered from the faeces and processed as indicated for ruminal incubations. Finally, bags were dried $\left(70^{\circ} \mathrm{C}\right.$ for $48 \mathrm{~h}$ ) and weighed to calculate the intestinal effective digestibility (IED) of DM. Then, the residues were pooled for each wether before CP analyses to determine IED of RUP. Additional details on ruminal and intestinal incubations, ruminal transit, ruminal degradation models, solid adherent bacteria isolation, microbial colonization, calculations and analytical procedures have been previously summarised ${ }^{2,13,15}$. Mean results of $k_{c}$ and $k_{p}$ rates, ruminal microbial contamination with crude protein (RMC), RUP, its IED and IDP were also presented in the former articles, as well as in Table 2.

\subsection{Chemical analyses}

This article is protected by copyright. All rights reserved. 
Analyses were performed according to the methods of the Association of Official Analytical Chemists ${ }^{16}$ for DM (air-forced oven dehydration; procedure 934.01), ash (incineration in muffle furnace; procedure 967.05), ether extract (ether extraction; procedure 920.39) and $\mathrm{CP}$ (Dumas $\mathrm{N} \times 6.25$; procedure 968.06). Feedstuff samples were analysed for $\mathrm{NDF}^{17}$, using a heat stable $\alpha$-amylase and without sodium sulphite, and for direct acid detergent fibre (ADF) and acid detergent lignin ${ }^{18}$. Both NDF and ADF were expressed inclusive of residual ash. Contents of neutral-detergent insoluble nitrogen (NDIN) and acid-detergent insoluble $\mathrm{N}$ (ADIN) were determined by $\mathrm{N}$ analysis of the respective fibre residues with the previously cited procedure for $\mathrm{N}$.

\subsection{Statistical analyses}

A covariance analysis using individual values was done in order to study the linear relationship between IDP and RUP considering the microbial contamination occurred in the rumen (c) as a fixed effect and RUP as linear covariate. The interaction between both variables was also included in the model: $\operatorname{IDP}_{i j}=\beta_{0}+\mathrm{c}_{i}+\beta_{1} \mathrm{RUP}_{i j}+\Sigma_{i} \beta_{2 i}(\mathrm{c} \times$ RUP $)_{i j}+\varepsilon_{i j}$, where $\beta_{0}, \beta_{1}, \beta_{2 i}$ are regression parameters. This analysis was developed with the GLM procedure of SAS (version 9.3) ${ }^{19}$.

\section{Results and discussion}

The covariance analysis showed that the close relationship found between IDP and RUP (Figure 1; IDP $=-0.0132( \pm 0.006795)+0.776( \pm 0.0002) \mathrm{RUP} ; \mathrm{n}=60 ; \mathrm{P}<0.001 ; \mathrm{R}^{2}=$ 0.960 ) is not affected by either the correction for ruminal microbial colonization or the RUP x microbial colonization interaction $(P=0.682$ and 0.991 , respectively). The lack of influence of the correction for microbial colonization indicates similar intersects for both microbial corrected and noncorrected data series, whereas the lack of significance of the interaction shows that both data series have the same regression slope. As a consequence, both noncorrected and corrected values can be used together to perform regression equations to predict IDP. As RUP and IDP data obtained considering effective RUP values are scarce in the literature, the possibility of using both types of values for this prediction is of great interest to attain accurate predictions. Using nonmicrobial corrected values from 35 samples of concentrates and co-products and 17 samples of forages, González ${ }^{20}$ showed negative relationships between IDP values and those of CP effective degradability with similar determination coefficients to those of

This article is protected by copyright. All rights reserved. 
the present study. This is in agreement with the positive relationship found with RUP, complementary value to that of degradability.

As shown in Table 2, not correcting the microbial colonization taking place in the rumen overestimates both RUP and IED and, therefore, their product (IDP) in sugar beet pulp ${ }^{13}$, rapeseed meal and palm kernel ${ }^{15}$. This same behaviour was observed in cereal grains and cereal co-products ${ }^{2}$, although in some feedstuffs of this group only a trend $(P<0.1)$ or just numerical differences (i.e. for IED values) were detected. Current colonization results of RUP are in agreement with the indications of Rodríguez and González ${ }^{21}$, who established that adherent microbial biomass is directly determined by the feed content in slowly degradable fractions such as corn-vitreous starch or fibre (specially cellulose) and inversely affected by the feed contents in undegradable components and lignin. These same authors showed that the contamination with microbial $\mathrm{N}$ decreases when the feed $\mathrm{N}$ content and its proportion bound to fibre increase. They also showed that the overestimations of RUP due to microbial colonization increase when RUP decreases and even more so when it is expressed as percentage. Thus, values of the microbial fraction in RUP as well as its associated overestimations were low in feeds rich in CP (distillers dried grains with solubles or rapeseed meal) or in fibre bound-N (palm kernel), whereas they were high in feeds with quickly degradable proteins (rye and wheat grains) or in low-protein feeds rich in slowly degradable components (fibre in dehydrated sugar beet pulp and vitreous starch in corn grain). As ruminal microorganisms that are adhered to feed particles are largely digested in the intestine $e^{2,13,15}$, the overestimation of the IED of RUP is not only defined by the magnitude of the ruminal colonization but mainly by the difference between the true intestinal digestibility of nitrogenous compounds from microorganisms and the truly undegraded feed fraction ${ }^{2,15}$. Thus, the overestimation of IED due to the ruminal microbial contamination in the sample set of Table 2 ranged from 0.7 to $43.7 \%$, being inversely proportional to noncorrected IED values as shown by the correlation coefficient between these parameters $(-0.883)$. In addition, it should be considered that any increase in ruminal degradation of a feed simultaneously increases the proportion of indigestible components in its post-ruminal outflow and thus causes a reduction in its true intestinal digestibility. Therefore, a greater degradation implies an increase in the overestimation of the IED of RUP associated with its microbial colonization. For example, the similar RUP overestimation observed in rye and corn grains $(22.1 \%$ and 
$22.5 \%$, respectively) was associated with an overestimation of the IED of RUP by almost 10 fold ( $43.7 \%$ vs. $4.40 \%$ ) in the rye grain (quickly and extensively degraded) compared with the corn grain (poorly degraded). As the digestion site (rumen or small intestine) affects the quantity of feed protein absorbed as amino acids, it is important to correct for ruminal microbial colonization in both rumen and intestine to obtain accurate evaluations of protein digestion. In this way, our results were obtained considering both $k_{c}$ and $k_{p}$ rates to take into account the real rumen residence time of feed particles. As a consequence of the extended degradation with the increase of the considered rumen residence time, the use of $k_{c}$ is associated not only with a reduction of the estimates of the by-pass fraction but also with a higher microbial colonization and enrichment in indigestible compounds of this by-pass, which also affect IED estimates ${ }^{2,15}$. Both microbial noncorrected and corrected values of IED were lower than the predictions of the INRA ${ }^{4}$ and $\mathrm{NRC}^{3}$ systems for protein intestinal digestibility, with the exception of the DDGS of wheat (values for DDGS of barley are not available in the literature) and of palm kernel. Thus, these predictions for corn grain, rye grain, wheat grain, corn gluten feed, DDGS of wheat, sugar beet pulp, rape seed and palm kernel were respectively: $0.88,0.90,0.92,0.85,0.85,0.80,0.85,0.79$ and $0.79\left(\right.$ INRA $\left.^{4}\right)$ and 0.90 , $0.80,0.95,0.85,0.80,0.75,0.80,0.75$ and $0.75\left(\mathrm{NRC}^{3}\right)$. Nevertheless, these systems omit the microbial colonization correction as well as $k_{c}$ and, as previously discussed, this results in an overestimation of the intestinal digestibility.

The lack of effect of the ruminal microbial colonization on the regression between IDP and RUP in spite of the large variation of the resulting overestimation of IDP values (from $5.33 \%$ in wheat distillers dried grains with solubles to $75.4 \%$ in rye grain) can be attributed to the large intestinal digestion of the $\mathrm{CP}$ of adherent microorganisms. Thus, the associated increases of CP in RUP estimates due to microbial colonization are largely eliminated by the intestinal digestion. The previously discussed modulated effects of microbial colonization correction, associated with the feed characteristics, on degradability and content of intestinal undigestible components may also contribute to the lack of this effect. The high determination coefficient $\left(\mathrm{R}^{2}=\right.$ 0.960) found for this prediction shows that values for protein rationing, such as IDP, may be predicted from RUP, simplifying the feed protein value determination which can be limited to the ruminal degradation studies. Microbial corrected and noncorrected data may be used together for this prediction, improving its accuracy.

This article is protected by copyright. All rights reserved. 


\section{Conclusions}

Ruminal and intestinal in situ digestion studies should consider ruminal microbial colonization to avoid errors regarding the digestion site when considering accurate protein evaluations of feedstuffs. The close relationship found between the contents of intestinal digested $\mathrm{CP}$ and ruminal undegraded $\mathrm{CP}$, which is not affected by this microbial colonization, allows a simpler evaluation of feed protein.

\section{Funding}

This work was supported by the CICYT-funded project (AGL 2006-08300).

\section{References}

1 González J, Sánchez L and Alvir MR, Estimation of intestinal digestibility of undegraded sunflower meal protein from nylon bag measurements. A mathematical model. Reprod Nutr Dev. 39: 607-616 (1999).

2 González J, Mouhbi R, Guevara-González J, Rodríguez CA and Arroyo JM, Protein value for ruminants of cereals and cereal co-products. Comparison between crude protein and protein-based estimates. Arch Anim Nutr. 69: 237-250 (2015).

3 National Research Council (NRC), Nutrient Requirements of Dairy Cattle. (7th rev. edn). National Academy Press, Washington, DC (2001).

4 INRA, Alimentation des Bovins, Ovins et Caprins. Besoins des Animaux - Valeurs des Aliments, Tables INRA 2007. Quae Editions, Versailles, France (2007).

5 Duinkerken G van, Blok MC, Bannink A, Cone JW, Dijkstra J, Vuuren AM van and Tamminga S. Update of the Dutch protein evaluation system for ruminants: the DVE/OEB 2010 system. J Agric Sci Camb. 149: 351-367 (2011).

6 Volden H (ed). 2011. Norfor- the Nordic feed evaluation system. EAAP publication No. 130. Wageningen Academic Publishers, Wageningen, The Netherlands.

This article is protected by copyright. All rights reserved. 
7 Ellis W, Matis $\mathrm{JH}$ and Lascano $\mathrm{C}$, Quantitating ruminal turnover. Federation Proceedings 38: 2702-2706 (1979).

8 González J, Ouarti M, Rodríguez CA and Alvir MR, Effects of considering the rate of comminution of particles and microbial contamination on accuracy of in situ studies of feed protein degradability in ruminants. Anim Feed Sci Technol. 125:89-98 (2006).

9 BOE. 2013. Royal Decree 53/2013 Febraury 1st on the protection of animals used for experimentation or other scientific purposes. Boletín Oficial del Estado 34: 1137011421 (2013). Available: https: //www.boe.es/boe/dias/2013/02/08/pdfs/BOE-A2013-1337.pdf (Accessed on 10 January 2016).

10 Dhanoa MS, Siddons RC, France J and Gale DL, A multicompartmental model to describe marker excretion patterns in ruminant faeces. Br J Nutr. 53:663-671(1985).

11 Rodríguez CA, González J, Alvir MR, Centeno C and Lamrani F, Composition of bacteria harvested from the liquid and solid fractions of the rumen of sheep as influenced by intake level. Br J Nutr. 84:369-376 (2000).

12 Ørskov ER and McDonald I, The estimation of protein disappearance in the rumen from incubation measurements weighted according to rate of passage. J Agric Sci Camb 9:499-503 (1979).

13 González J, Arroyo JM, Guevara-González JA, Mouhbi R, Piquer O and Moya VJ, Effects of the comminution rate and microbial contamination of particles in the rumen on accuracy of in situ estimates of digestion of protein and amino acids of dehydrated sugar beet pulp. J Agric Sci Camb. 152:166-174 (2014).

14 Arroyo JM and González J, Effects of the ruminal comminution rate and microbial contamination of particles on accuracy of in situ estimates of ruminal degradability This article is protected by copyright. All rights reserved. 
and intestinal digestibility of feedstuffs. J Anim Physiol Anim Nutr. 97:109-118 (2013).

15 González J, Arroyo JM, Guevara-González J, Mouhbi R, Piquer O and Moya VJ, Effects of the comminution rate and microbial contamination of particles in the rumen on in situ estimates of protein and amino acid digestion of expeller palm kernel and rapeseed meal. J Sci Food Agr. 94:1291-1298 (2014).

16 Association of Official Analytical Chemists. AOAC, 1999. Official Methods of Analysis, 16th ed., 5th revision. AOAC International, Gaithersburg, MD, USA.

17 Van Soest PJ, Robertson JB and Lewis BA, Methods for dietary fiber, neutral detergent fiber and non starch polysaccharides in relation to animal nutrition. J Dairy Sci. 74:3583-3597 (1991).

18 Robertson JB and Van Soest PJ, The detergent system of analysis and its application to human foods. In: James WPT, Theander O, editors. The Analysis of Dietary Fibre in Foods. New York: Marcel Dekker. p. 123-158. (1981).

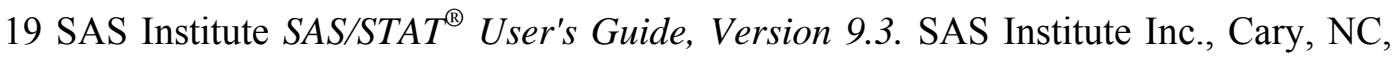
USA (2008).

20 González J, Ruminal utilization of feed protein in ruminants (in Spanish) in Avances en nutrición y alimentación animal. ed by Rebollar PG, de Blas C and Mateos GG. Fundación Española para el Desarrollo de la Nutrición Animal. Madrid pp 203-216 http://fundacionfedna.org/sites/default/files/06CAP_XII.pdf [12 December 2016] (2006).

21 Rodríguez CA and González J, In situ study of the relevance of bacterial adherence to feed particles on the contamination and accuracy of rumen degradability estimates of feeds of vegetable origin. Br J Nutr. 96:316-325 (2006).

This article is protected by copyright. All rights reserved. 
Table 1: Chemical fractions ${ }^{\mathrm{a}}\left(\mathrm{g} \mathrm{kg}^{-1}\right.$ dry matter unless otherwise stated) ín tested feeds and diet ingredients

\begin{tabular}{lccccccccc}
\hline Feeds & DM (\%) & OM & CP & Lipids & NDF & ADF & Lignin $^{\text {NDIN }^{\mathrm{b}}}$ ADIN $^{\mathrm{b}}$ \\
\hline Corn grain & 905 & 987 & 87.8 & 33.8 & 98.8 & 19.0 & 5.41 & 77.7 & 9.20 \\
Rye grain & 874 & 985 & 126 & 15.5 & 139 & 32.8 & 5.62 & 93.4 & 14.4 \\
Wheat grain & 878 & 984 & 137 & 20.1 & 128 & 33.7 & 6.53 & 77.5 & 7.50 \\
Corn gluten feed & 923 & 931 & 175 & 27.1 & 371 & 104 & 8.13 & 83.3 & 23.3 \\
DDGS barley & 910 & 949 & 232 & 58.5 & 457 & 159 & 47.8 & 347 & 55.8 \\
DDGS wheat & 891 & 950 & 346 & 75.0 & 454 & 121 & 46.1 & 426 & 55.8 \\
Wheat bran & 891 & 945 & 138 & 32.7 & 411 & 147 & 45.5 & 265 & 57.9 \\
Sugar beet pulp & 908 & 952 & 99.0 & 5.60 & 474 & 234 & 39.6 & 365 & 68.0 \\
Rapeseed meal & 916 & 917 & 350 & 29.2 & 338 & 252 & 121 & 239 & 137 \\
Palm kernel & 915 & 953 & 141 & 92.8 & 651 & 374 & 104 & 756 & 221 \\
Diet-oat hay & 904 & 889 & 129 & - & 536 & 301 & 48.8 & - & - \\
Diet-concentrate & 882 & 937 & 149 & - & 135 & 43.0 & 7.81 & - & - \\
\hline
\end{tabular}

${ }^{\mathrm{a}} \mathrm{DM}$, Dry matter; OM, Organic matter; CP, Crude protein; NDF and ADF, Neutral and acid detergent fibre, respectively; NDIN and ADIN, N insoluble in neutral and acid fibre solutions, respectively.

${ }^{b} \mathrm{~N} \mathrm{~kg}^{-1} \mathrm{~N}$

${ }^{e}$ DDGS, Distillers'dried grains with solubles. 
Table 2. Mean data of the ruminal microbial contamination (RMC), the ruminally undegraded crude protein fraction (RUP), its intestinal effective digestibility (IED) and the intestinal digested crude protein (IDP) noncorrected (NC) and corrected (C) by RMC of different feeds (values estimated based on particle comminution $\left(k_{c} ; 0.734 \mathrm{~h}^{-1}\right)$ and outflow $\left(k_{p} ; 0.0450 \mathrm{~h}^{-1}\right)$ rates and expressed as proportions).

\begin{tabular}{|c|c|c|c|c|c|c|c|}
\hline & \multirow[b]{2}{*}{$\mathrm{RMC}^{\mathrm{d}}$} & \multicolumn{2}{|c|}{ RUP } & \multicolumn{2}{|c|}{ IED of RUP } & \multicolumn{2}{|c|}{ IDP } \\
\hline & & $\mathrm{NC}$ & $\mathrm{C}$ & $\mathrm{NC}$ & $\mathrm{C}$ & $\mathrm{NC}$ & $\mathrm{C}$ \\
\hline Corn grain ${ }^{a}$ & 0.187 & 0.185 & 0.151 & 0.830 & 0.795 & 0.154 & 0.120 \\
\hline Rye grain ${ }^{a}$ & 0.179 & 0.059 & 0.048 & 0.408 & 0.284 & 0.024 & 0.014 \\
\hline Wheat grain ${ }^{\mathrm{a}}$ & 0.161 & 0.047 & 0.040 & 0.550 & 0.473 & 0.026 & 0.019 \\
\hline Corn gluten feed $^{\mathrm{a}}$ & 0.146 & 0.181 & 0.155 & 0.648 & 0.586 & 0.117 & 0.091 \\
\hline DDGS barley $^{\mathrm{a}}$ & 0.065 & 0.248 & 0.232 & 0.849 & 0.843 & 0.211 & 0.196 \\
\hline DDGS wheat $^{\mathrm{a}}$ & 0.036 & 0.353 & 0.340 & 0.911 & 0.898 & 0.322 & 0.305 \\
\hline Wheat bran ${ }^{\mathrm{a}}$ & 0.145 & 0.222 & 0.191 & 0.587 & 0.516 & 0.130 & 0.099 \\
\hline Sugar beet pulp ${ }^{b}$ & 0.201 & 0.466 & 0.372 & 0.679 & 0.603 & 0.316 & 0.224 \\
\hline Rapeseed meal $^{\mathrm{c}}$ & 0.046 & 0.408 & 0.389 & 0.709 & 0.691 & 0.289 & 0.269 \\
\hline Palm kernel $^{\mathrm{c}}$ & 0.064 & 0.685 & 0.641 & 0.761 & 0.749 & 0.521 & 0.480 \\
\hline
\end{tabular}

$\overline{\mathrm{a}, \mathrm{b} \text { and } \mathrm{c}}$ Data from references 2,13 and 15 , respectively.

${ }^{\mathrm{d}}$ as proportion of RUP.

This article is protected by copyright. All rights reserved. 


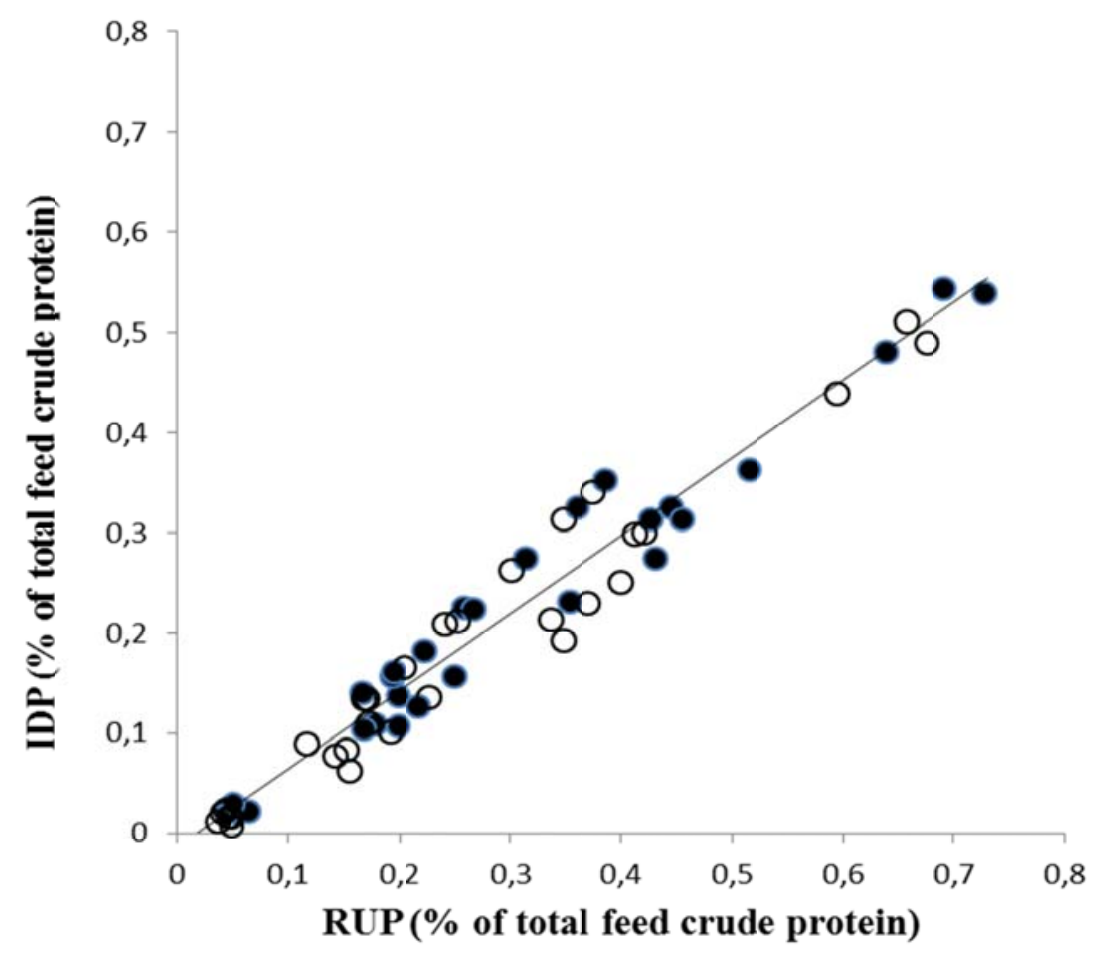

Figure 1. Relationship in ten concentrates and by-products between the intestinal digested protein (IDP) and the ruminal undegraded protein (RUP). IDP $=-0.0132( \pm$ $0.006795)+0.776( \pm 0.0002) \mathrm{RUP} ; \mathrm{n}=60 ; \mathrm{P}<0.001 ; \mathrm{R}^{2}=0.960$. Values corrected $(\bigcirc$ ) or noncorrected (1) for the microbial colonization in the rumen. Probability of other effects: colonization correction: $P=0.682$; colonization correction $\times$ RUP: $P=0.991$. 